\title{
RADON CHANGES ALONG MAIN FAULTS IN THE BROADER AIGION REGION, NW PELOPONNESE
}

\author{
Katsanou K. ${ }^{1}$, Stratikopoulos K. ${ }^{1}$, Zagana E. ${ }^{1}$ and Lambrakis N. ${ }^{1}$ \\ ${ }^{1}$ University of Patras, Department of Geology, Laboratory of Hydrogeology, 26500 Patras, \\ katsanou@upatras.gr
}

\begin{abstract}
In the present study the relationship between Rn and hydrochemical parameters in groundwater samples with the intense tectonics that prevail in the broader region of Aigion were investigated. Radon concentrations were measured in water samples collected from the unconfined aquifer, hosted in Plio-Pleistocene deposits, along the major faults of the research area. The spatial distribution of radon concentrations revealed the existence of three distinct zones along Aigion, Pyrgaki and Helike faults, respectively. The first two zones are characterized by high radon concentrations, whereas the third by low radon concentrations. It is also shown that ${ }^{222} \mathrm{Rn}$ and $\mathrm{CO}_{2}$ concentrations display similar spatial distribution suggesting a common origin for these two gases, with $\mathrm{CO}_{2}$ being the major carrier gas for radon in deep fluids. The deformation and fragmentation of rocks along the fault zones enables the circulation of those fluids resulting in elevated radon concentrations in groundwater. However, other factors, such as the mineralogical composition of the sediments along the fault planes may restrict this process. The distribution of radon along the fault zones suggests that radon measurements can be used as a tool for the detailed mapping of active faults and if combined with seismic data even as a tool for study earthquake prediction.
\end{abstract}

Key words: Radon 222, groundwater, fault tracing, Aigion.

\section{Introduction}

Radon $\left({ }^{222} \mathrm{Rn}\right)$ is a daughter nuclide of radium $\left({ }^{226} \mathrm{Ra}\right)$, which in turn derives from the long-living antecedent, uranium $\left({ }^{238} \mathrm{U}\right)$. The short half-life of ${ }^{222} \mathrm{Rn}$ (3.85 days) produced at great depth, limits its migration distance in the subsoil, unless it is lifted upward by a relatively fast-flowing carrier gas, such as $\mathrm{CO}_{2}, \mathrm{CH}_{4}$, or $\mathrm{N}_{2}$, (Moussa et al., 2003 and references therein).

The amount of radon emitted from the Earth's crust into the atmosphere is usually small. However, unusual quantities of radon could be emitted above geological faults, geothermal sources, uranium deposits and volcanoes (Nishimura \& Katsura, 1990).

Durrani \& Ilic (1997) discussed the relation between geology and radon levels in groundwater, soil gas, and indoor air. Radium, the immediate precursor of radon gas, occurs virtually in all types of rocks and soils; its concentration varies from site to site depending on geological factors (Al-Tamimi \& Abumurad, 2001).

Water and geo-gas discharges are strongly promoted in hydrothermal systems and seismically active zones. The distribution of radon in soil gas has therefore been applied in the exploration of ge- 
othermal energy fields, the monitoring of volcanic activity, the prediction of earthquakes and the mapping of fault zones (Ioannides et al., 2003 and references therein).

The high permability, compared to the surrounding country rocks, that is often exhibited along fault zones often can turn fault zones into preferential pathways for adjective gas-carrying fluid transport. During their way to the surface, pressure decrease allows the gases $\left(\mathrm{CH}_{4}, \mathrm{CO}_{2}, \mathrm{He}, \mathrm{Hg}\right.$, $\mathrm{Rn}$, etc.) to escape from the fluids into soil gas and eventually into the atmosphere (King, 1986).

Anomalously high radon concentration in ground water has long been associated with faults. In addition to hydrological studies, numerous radon concentration determinations in ground waters and in soil gas have been performed in many seismically active areas in several countries, in order to elaborate a methodology to predict earthquakes. As known radon monitoring in soil gas and waters has been shown to be a promising method for predicting earthquakes. Radon levels are correlated with meteorological and hydrological data as well as with seismic activity, and often, abrupt changes in radon levels appear as precursors of earthquakes (King, 1986).

The radon variations are also caused by changes in meteorological parameters such as temperature, atmospheric pressure, wind velocity, humidity, rainfall, etc. The correlation of radon emission with meteorological factors is extremely useful for discriminating the genuine from spurious signals and has repeatedly been discussed (Singh et al., 1999).

It is found that the amplitude and shape of radon anomalies depend on the extent of fracturing, the dip angle, the type of rocks involved, the width of rupture zone, the permeability of fault-zone materials, the thickness and composition of the top-soil layer, the geomorphology, and the surface vegetation. Gas surveys are an effective method for locating unmapped faults provided that active faults are enriched in terrestrial gases due to the fact that they constitute significant "leaks" for the Earth's outgassing process (King, 1990, 1993).

Fractures and faults provide permeable pathways for fluids at a variety of scales, from great depths in the crust, to flow through fractured aquifers, geothermal fields and hydrocarbon reservoirs. Fracture-enhanced permeability depends on fracture density, orientation, and, mostly on the hydraulic conductivity of the different fractures and fault planes (Barton et al., 1995).

We aimed at gaining new insights on relationships between major tectonic features, including active and seismogenic structures, and fluid geochemistry on a regional scale in Aigion area (N. Peloponnese). Our main target was to identify geochemically anomalous areas characterized by the deepening of the hydrological circuits due to the presence of enhanced faulting and fracturing shown by spatial radon anomalies.

\section{Aigion Region}

\subsection{Geological and hydrogeological setting}

Geologically, the area belongs to the Olonos- Pindos isopic zone (Fig. 1a). The zone overthrusts towards the west the Gavrovo-Tripoli isopic zone and is composed of deep-sea sedimentary rocks deposited from the Triassic until the Palaeocene, when syn-orogenic turbiditic sedimentation commenced lasting until the Upper Eocene.

The pre-orogenic sequence of the zone is thought to represent a passive continental margin of the Apulian micro- continent (Degnan \& Robertson, 1998). The bottom of the sequence is composed of Triassic clastic and carbonate rocks, which were deposited during the early stages of the Pindos 


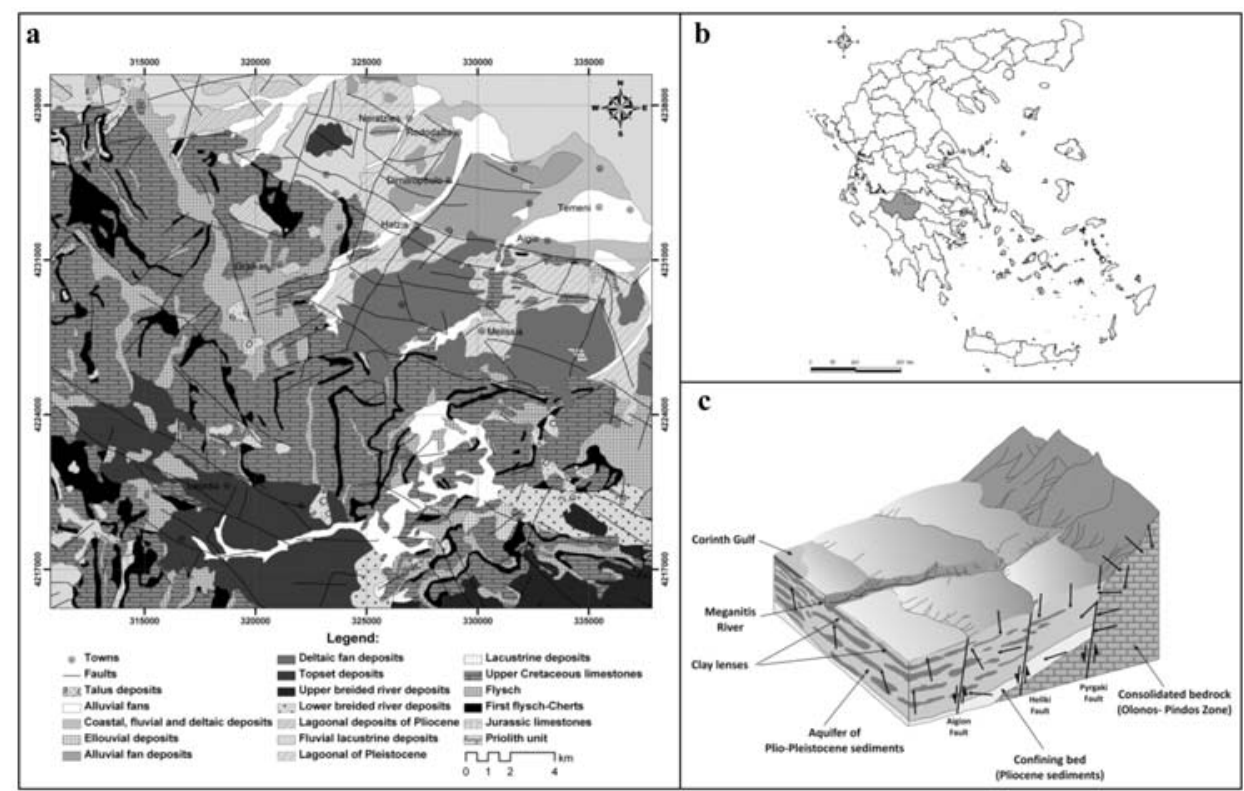

Fig. 1: a: Geological map of the region (Nikas, 2004), (b): geographical setting of Aigion region, (c): Schematic block diagram of the region.

ocean formation (Pe- Piper \& Piper, 1991). A comformable unit of pelagic limestones with red shale and siltstone intercalations deposited form the Late Karnian until the Liassic overlie the Triassic unit. During the Early Doggerian-Tithonian the red chert (radiolarite) unit was deposited. It represents a phase of rifting and is composed of red and green cherts accompanied by thin-bedded micritic limestones (Fleury, 1980). At the end of the Tithonian, a clastic unit composed of turbidite sediments, which derived from elevated parts of the Internal Hellenides to the East, was deposited and is usually referred as the "First Flysch" (Skourlis \& Doutsos, 2003). The Mesozoic sequence ends with the deposition of platy pelagic limestones of Senonian age (Upper Cretaceous).

The pre-orogenic formations are overlain by a Flysch sequence deposited during Palaeocene and Eocene times, through a transitional sequence of Maastrichtian age. The Olonos- Pindos zone is heavily deformed by folds with NNW-SSE trending axes and thrust faults dipping to the NE and trending NW-SE (Skourlis \& Doutsos, 2003).

The Upper Cretaceous limestones are the most permeable formation of the Olonos Pindos zone. They form a heterogeneous, slightly karstified aquifer that consists of carbonate beds of small thickness with chert intercalations. This aquifer, which is one of the major aquifers in the region lies in depth of 100 $\mathrm{m}$ and is extended to the Corinth Gulf where, it is discharged through sub marine springs.

Considering its hydraulic conductivity $(\mathrm{k})$, it displays values that range between $7.1 \times 10^{-5}$ and $6.7 \times 10^{-3}$ $\mathrm{m} / \mathrm{s}$ (Nikas, 2004). The joint network and the extension of the joints due to dissolution are factors that affect the movement and storage of water. Chert and flysch interferences form autonomous hydrogeological units which result in the presence of many low discharge springs $\left(14-55 \mathrm{~m}^{3} / \mathrm{h}\right)$.

A sequence of Plio-Pleistocene sediments as well as Holocene fluvial deposits was deposited uncomformably above the Pindos zone formations. The sediments within the drainage basins are distinguished into three different facies, lacustrine- lagoonal marls, and marine sandstone, forming 


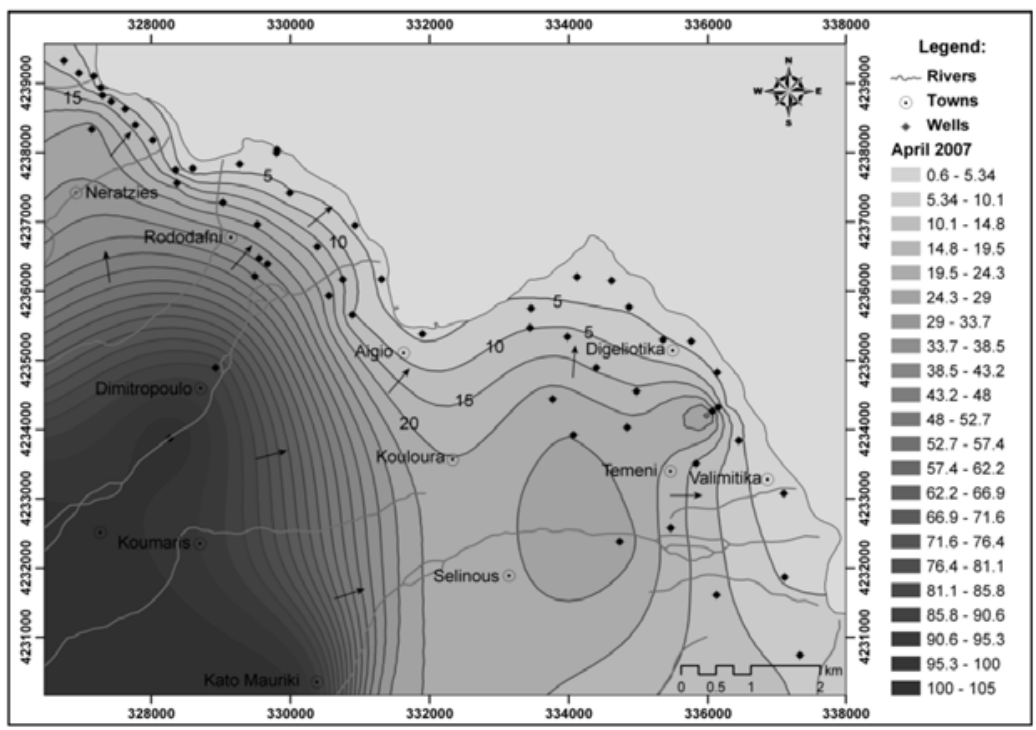

Fig. 2: Map showing of potentiometric surface (April 2007).

elevated terraces, and coarse-grained braided river or fan delta deposits (Poulimenos et al., 1989). Lacustrine-lagoonal marls are composed of coarsening upwards cycles with mudstone and silty sandstone beds (Zelilidis, 2000). Near bounding faults coarse-grained massive, matrix-supported, high dipping conglomerates accumulated. Moreover, in transfer zones thick interbedded mudstonesandstone and conglomerate beds were deposited. Marine sandstone terraces are common in the northeastern part of the basin. Fan delta deposits include subaerial and sub-aqueous facies consisting of thick conglomeratic deposits (Poulimenos, 1993; Poulimenos et al., 1993). Their particle size differs with depth but also horizontally. The Plio-Pleistocene sediments are dipping towards the East and their thickness is increasing. The thickness of lacustrine-lagoonal deposits of Lower Pleistocene and alluvial deposits is increasing northwards and eastwards respectively.

The Plio-Pleistocene sediments form a uniform, unconfined aquifer with diverse permeability which is the second major aquifer of the area. Its hydraulic conductivity varies between $1.81 \times 10^{-4}$ and $7.00 \times 10^{-3} \mathrm{~m} / \mathrm{s}$ (Nikas, 2004). From the potentiometric map (Fig. 2) it is shown that the Upper Pleistocene-Holocene alluvial fan in the plain area form a common water table due to contact of the aquifers that are hosted in the Plio-Pleistocene deposits. Moreover, along Selinous and Meganeitis river beds there is a zone of high fresh water income. Groundwater follows two main directions, one SE-NW and a second of SW-NE. The hydraulic gradient ranges between $4 \% 0-6 \%$ for the entire area, however along Selianitika village the hydraulic gradient reaches values that range between 15$20 \%$. The seasonal water table variations vary from 0.40 to $0.60 \mathrm{~m}$.

The impermeable layer of the lacustrine-lagoonal sediments is the base of this aquifer, but also acts as the confining layer of the karstic aquifer. The aquifer of Plio-Pleistocene sediments is in many sites in direct contact with the karstic aquifer.

The aquifers are recharged mainly from direct infiltration of precipitation and river bed indirect infiltration. Direct infiltration also takes place in karstic aquifer along the outcrops of carbonate aquifer in the lowlands of the study area. 


\subsection{Tectonics}

The eastern termination of the Corinth Gulf is a tectonically important area over the whole Greek Peninsula because of its high earthquake activity (Koukouvelas \& Doutsos, 1996). A detailed mapping of the faults and formations has been carried out from many researchers (Poulimenos et al., 1989, Poulimenos, 1993; Doutsos et al., 1993; Koukouvelas et al., 1996, 1998, 2001; Zelilidis 2000; Pavlides et al., 2004), whereas uplifted shorelines, reversal of drainage patterns, earthquake induced landslides, both on land and offshore, faulted colluvial layers and historical and recent seismic activity provide evidence for the active deformation in the Gulf (Koukouvelas et al., 2001; Pavlides et al., 2004).

Furthermore, several geodetical surveys conducted in the area have shown that the Gulf of Corinth is at the present one of the most rapidly extending regions worldwide with an average extension rate between 4 and 14 mm/year (Clarke et al., 1998, Briole et al., 2000, Avalone et al., 2004).

Five active normal faults in the southern part of Aigion region namely, from south to north, the Pyrgaki, Melissia, Kerinia, Eliki and Aigion faults, control the accumulation of sediments at the western end of the Gulf of Corinth. These major faults, which control the environments of sedimentation of the Plio-Pleistocene deposits, also influence the configuration of hydrogeological units and the hydrology of the region.

\section{Materials and methods}

\subsection{Sampling of groundwater and analytical procedures}

In order to define the hydrochemical composition of the aquifer of the Plio-Pleistocene formation a total number of 18 samples were collected during May 2007 from springs and boreholes along the major faults of the region according to US EPA (1976) procedures. This choice arose from geological and structural considerations but also taking into consideration all the previous studies that have been carried out in the region. The sampling sites included 4 shallow wells, 11 cold springs as well as one spring with relatively elevated Tw $\left(19^{\square} \mathrm{C}\right)$ and a borehole with artesian flow, evident for deep flow circuits.

Two polyethylene bottles of 1 and 0.1 L volume, respectively were collected at each sampling site; the former containing bulk water sample for anion concentration analyses and the latter filtered $(0.45$ $\mu \mathrm{m})$ and acidified with $0.5 \mathrm{~mL}$ ultrapure $\mathrm{HNO}_{3}$.

The unstable physicochemical parameters $\left(\mathrm{T}_{\mathrm{w}}, \mathrm{pH}, \mathrm{Ec}, \mathrm{O}_{2}\right.$ and Eh) were measured in situ, using Consort ${ }^{\circledR}$ portable equipment. Additionally, alkalinity, $\mathrm{CO}_{2}$ and $\mathrm{H}_{2} \mathrm{~S}$ concentrations were measured at the site using $\mathrm{Hach}^{\circledR}$ Digital Titrator and $\mathrm{Hach}^{\circledR}$ DR 2400 portable spectrophotometer, respectively. Anion $\left(\mathrm{NO}_{3}{ }^{-}, \mathrm{NO}_{2}{ }^{-}, \mathrm{PO}_{4}{ }^{3-}, \mathrm{SO}_{4}{ }^{2-}\right.$, and $\left.\mathrm{F}^{-}\right), \mathrm{SiO}_{2}$ and $\mathrm{NH}_{4}{ }^{+}$concentrations were measured in a $\mathrm{Hach}^{\circledR}$ DR 4000 spectrophotometer except from $\mathrm{Cl}^{-}$, which was measured using titration. Major cation $\left(\mathrm{Ca}^{2+}, \mathrm{K}^{+}, \mathrm{Mg}^{2+}, \mathrm{Na}^{+}\right)$concentrations were determined in a $\mathrm{GBC}^{\circledR}$ Avanta flame atomic absorption spectrophotometer. Trace element concentrations were measured using inductively coupled plasma-mass spectrometry (ICP-MS) in an ELAN 6100 Perkin-Elmer.

\subsection{Measurement of Dissolved Radon and Thoron}

Radon concentration in groundwater was measured using a portable radonmeter (SARAD RTM 2050). Radon levels in groundwater along the five different well-known traceable fault planes were measured. Every sample was measured directly after the sampling on a $2 \mathrm{~h}$ cycle. The error did not exceed $10 \%$ for the total number of samples. All measurements were reported in $\mathrm{Bqm}^{-3}$. 
Table 1. Descriptive statistics for water samples $(n=17)$.

\begin{tabular}{|c|c|c|c|c|c|}
\hline & units & mean & $\min$ & $\max$ & St dev \\
\hline $\mathrm{pH}$ & & 7.30 & 6.91 & 8.23 & 0.35 \\
\hline Eh & $\mathrm{mV}$ & 53.23 & -219.00 & 153.00 & 116.50 \\
\hline Tw & ${ }^{\circ} \mathrm{C}$ & 16.95 & 12.10 & 20.70 & 2.77 \\
\hline E.C. & $\mu \mathrm{S} / \mathrm{cm}$ & 786.54 & 204.00 & 1280.00 & 365.43 \\
\hline Th & $\mathrm{Bqm}^{-3}$ & 378.50 & 223.00 & 433.00 & 103.71 \\
\hline Rn & $\mathrm{kBqm}^{-3}$ & 3.07 & 1.10 & 6.70 & 1.94 \\
\hline $\mathbf{H}_{2} \mathrm{~S}$ & $\mathrm{mg} / \mathrm{l}$ & 0.02 & 0.00 & 0.30 & 0.08 \\
\hline $\mathrm{CO}_{2}$ & $\mathrm{mg} / \mathrm{l}$ & 128.23 & 57.00 & 267.00 & 53.39 \\
\hline $\mathrm{Na}^{+}$ & $\mathrm{mg} / \mathrm{l}$ & 37.42 & 2.10 & 282.00 & 67.44 \\
\hline $\mathbf{K}^{+}$ & $\mathrm{mg} / \mathrm{l}$ & 2.87 & 0.37 & 11.79 & 3.88 \\
\hline $\mathrm{Mg}^{2+}$ & $\mathrm{mg} / \mathrm{l}$ & 10.70 & 1.46 & 48.68 & 12.05 \\
\hline $\mathrm{Ca}^{2+}$ & $\mathrm{mg} / \mathrm{l}$ & 105.32 & 7.45 & 190.00 & 49.51 \\
\hline $\mathrm{NH}_{4}^{+}$ & $\mathrm{mg} / \mathrm{l}$ & 0.30 & 0.00 & 3.28 & 0.85 \\
\hline $\mathbf{F}^{-}$ & $\mathrm{mg} / \mathrm{l}$ & 0.64 & 0.00 & 8.20 & 1.90 \\
\hline $\mathrm{HCO}_{3}^{-}$ & $\mathrm{mg} / \mathrm{l}$ & 310.23 & 145.30 & 601.50 & 120.00 \\
\hline $\mathrm{Cl}^{-}$ & $\mathrm{mg} / \mathrm{l}$ & 16.43 & 0.00 & 73.10 & 20.14 \\
\hline $\mathrm{SO}_{4}{ }^{2-}$ & $\mathrm{mg} / \mathrm{l}$ & 124.19 & 1.60 & 654.00 & 173.01 \\
\hline $\mathrm{NO}_{3}^{-}$ & $\mathrm{mg} / \mathrm{l}$ & 10.50 & 0.00 & 109.00 & 25.35 \\
\hline $\mathrm{NO}_{2}^{-}$ & $\mathrm{mg} / \mathrm{l}$ & 0.02 & 0.00 & 0.06 & 0.01 \\
\hline $\mathrm{SiO}_{2}$ & $\mathrm{mg} / \mathrm{l}$ & 10.27 & 0.70 & 25.10 & 5.59 \\
\hline $\mathbf{L i}$ & $\mu \mathrm{g} / \mathrm{l}$ & 15.63 & 0.61 & 36.32 & 14.26 \\
\hline $\mathbf{U}$ & $\mu \mathrm{g} / \mathrm{l}$ & 0.44 & 0.04 & 2.30 & 0.76 \\
\hline B & $\mu \mathrm{g} / \mathrm{l}$ & 340.30 & 31.95 & 846.00 & 441.45 \\
\hline $\mathrm{Sr}$ & $\mu \mathrm{g} / \mathrm{l}$ & 995.83 & 98.40 & 2480.17 & 980.05 \\
\hline
\end{tabular}

The ${ }^{222} \mathrm{Rn}$ gas concentration is measured by the short living daughter products, generated by the radon decay inside a measurement chamber. Directly after the decay, the remaining ${ }^{218}$ Po nuclei become charged positively for a short period, because some shell electrons are scattered away by the emitted alpha particle. Those ions are collected by the electrical field forces on the surface of a semiconductor detector. The collection of the short living daughter products on the surface of a semiconductor detector allows the separation of the single nuclides, with respect to their emission energy. The equilibrium between radon decay rate and ${ }^{218}$ Po detector activity is given after about 5 half-life times (15 min). This time span defines the minimum achievable response time to a radon concentration step. The decay chain is continued by both beta emitters ${ }^{214} \mathrm{~Pb}$ and ${ }^{214} \mathrm{Bi}$ followed by another alpha emitter, the ${ }^{214} \mathrm{Po}$. The emission energies of ${ }^{218} \mathrm{Po}$ and ${ }^{214} \mathrm{Po}$ are different and therefore, it is possible to distinguish between the two nuclides by means of alpha spectroscopy. In case of ${ }^{220} \mathrm{Rn}$, the direct daughter product ${ }^{216} \mathrm{Po}$, which also underlies the ionisation process, is used to calculate ${ }^{220} \mathrm{Rn}$ activity concentration. The half-life of ${ }^{216} \mathrm{Po}$ is less than $1 \mathrm{~s}$ and therefore the equilibrium state between gas concentration and collected activity on the detector is present immediately. The single nuclides of ${ }^{220} \mathrm{Rn}$ decay chain will also be distinguished by alpha spectroscopy. 


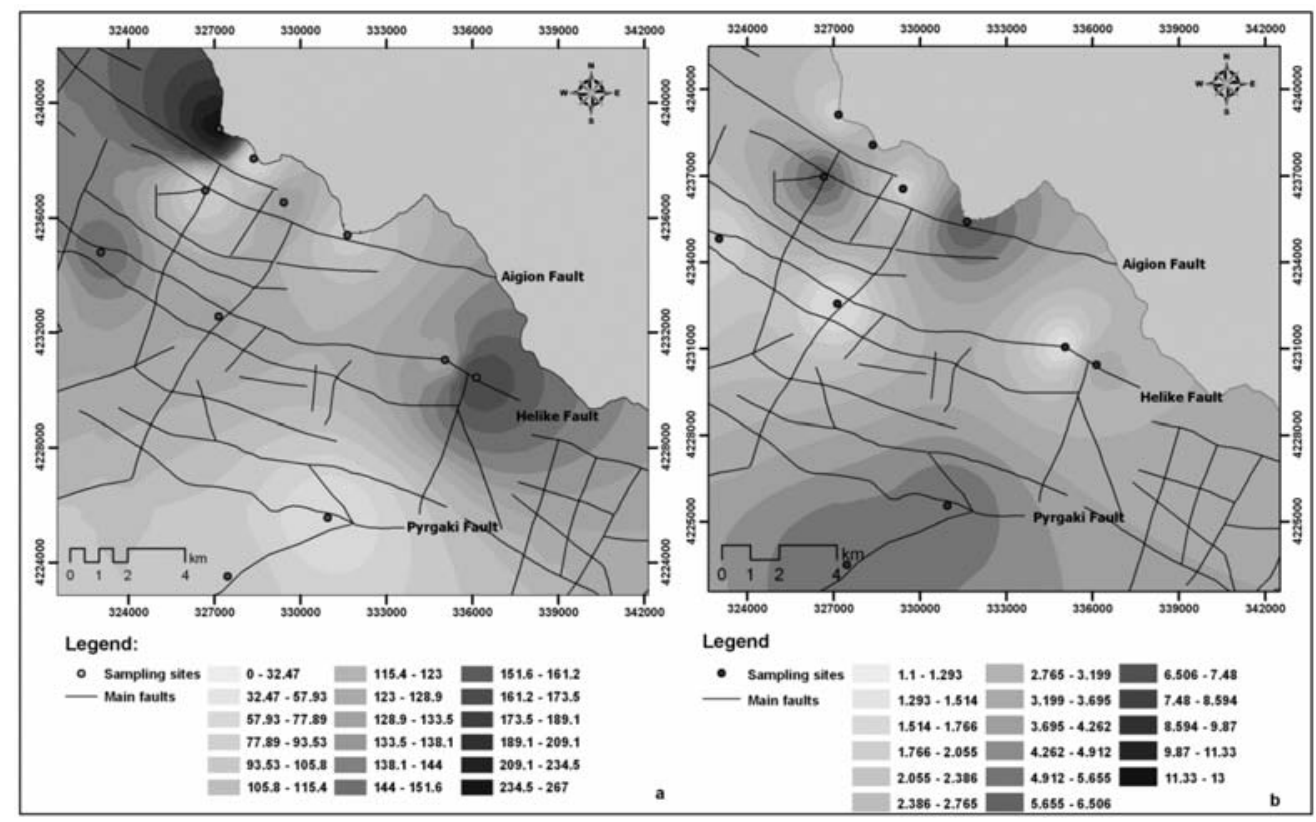

Fig. 3: Spatial distribution of measured values of (a) CO2 (b) Radon for the study area.

\section{Results and discussion}

Groundwaters of the study area can be grouped in three main hydrochemical types $\left(\mathrm{Ca}-\mathrm{HCO}_{3}, \mathrm{Ca}-\right.$ $\mathrm{HCO}_{3}-\mathrm{SO}_{4}$ and $\mathrm{Na}-\mathrm{HCO}_{3}$ ). The $\mathrm{CaHCO}_{3}$ water type prevails in the central part, though the other two types are found in the eastern and western margins of the area and are accompanied with a shift in $\mathrm{NH}_{4}{ }^{+}, \mathrm{SO}_{4}{ }^{2-}, \mathrm{Na}^{+}, \mathrm{K}^{+}, \mathrm{F}^{-}$and $\mathrm{HCO}_{3}{ }^{-}$concentrations, as well as, enrichment in certain trace elements, such as B, Li, U. The descriptive statistics of the collected samples are shown in Table 1.

The measured radon concentrations vary between 1 and $8.2 \mathrm{kBqm}^{-3}$. The measured values for Aigion fault are consistent with those measured in soils from Richon et al, 2007 in the same region. As it is pointed out from the spatial distribution of ${ }^{222} \mathrm{Rn}$ (Fig. 3), along the Aigion, Pyrgaki and Helike faults three zones of elevated values are formed. Groundwater in the first two appears to have elevated values of Rn that reach $4 \mathrm{kBqm}^{-3}$ on average, for Aigion fault and $6.5 \mathrm{kBqm}^{-3}$ on average, for Pyrgaki fault. These anomalies can be related to the expected changes of rock properties along these fault zones, such as a large increase in the porosity and permeability of the deformed rocks. Through this porous and permeable medium, radon migrates upwards more easily (King, 1980; Kresl et al., 1993; Gudmundsson et al., 2001), whereas grain size reduction also affects uranium-bearing minerals found in the rock body resulting in an increase in radon emanation (Gundersen and Linda, 1991). This comes to an agreement with the existence of zeolites in the fault cores, evident of upward moving fluids from depth, during successive earthquakes (Koukouvelas and Papoulis, 2009).

The third zone is located along both eastern and western part of the Helike fault (Fig. 3) and appears to have unexpectedly low values $\left(1.5 \mathrm{kBqm}^{-3}\right.$, on average). In contrast to the other two fault zones the Helike fault appears to be sealed with clay minerals (Koukouvelas \& Papoulis, 2009) suggesting a profound decrease in the permeability of the fractured zone resulting in restricted fluid circulation. Additionally, the same authors report, that the comparison of the mineralogical composition 
of sediments along the planes of Pyrgaki and Aigion Faults and the presence of significant quantities of chlorite along their cores suggest deeper fluid circulation than the Helike Fault.

Radon has been used both to locate buried faults and to monitor faults for predicting earthquake activity. Anomalous high radon concentrations has been measured along many active faults worldwide (King 1986, 1990, 1993; Nishimura \& Katsura, 1990; Kresl et al., 1993; Barton et al., 1995; Singh et al., 1999; Mancini et al. 2000; Gudmundsson et al., 2001; Ioannides et al., 2003; Moussa et al., 2003; Pizzino et al., 2004a, b; Richon et al., 2007). The Helike and Aigion faults are hosting strong and moderate earthquakes, respectively characterized by high slip rate (Koukouvelas \& Doutsos, 1996, Tselentis et al. 1996). According to Koukouvelas \& Papoulis (2009) although the Pyrgaki fault appears to have rather limited seismicity and generate moderate earthquakes, it is reasonable to suggest that it was much more seismically active in the past, taking into consideration that all faults control fan-deltas.

Furthermore oxidation of iron during faulting, deformation and subsequent weathering, results in distinctive iron-staining nature of many fault zones. Iron oxides and other metal oxides scavenge uranium and radium available through the weathering processes. These processes increase the radon emanation from rocks and soils, and make radon readily available to local groundwater (Al-Tamimi $\&$ Abumurad, 2001). Another source of high radon $\left({ }^{222} \mathrm{Rn}\right)$ values in the region could be connected with the carbonate rocks which appear to be enriched in U (Pizzino et. al., 2004a).

Two secondary zones with high ${ }^{222} \mathrm{Rn}$ concentrations were traced perpendicularly to the three major zones in the NW and NE margins of the region (Fig. 3). These anomalies coincide with hydrochemical differentiation noticed in these areas (Katsanou, 2007). The higher Ec and $\mathrm{CO}_{2}, \mathrm{Na}, \mathrm{SiO}_{2}$, $\mathrm{F}^{-}, \mathrm{SO}_{4}, \mathrm{HCO}_{3}, \mathrm{Li}, \mathrm{U}$ contents together with their relatively high temperatures (up to $21^{\square} \mathrm{C}$ ) testify both, deep hydrological circuits and longer lasting water-rock interaction processes compared to the other shallow aquifers discharging throughout the entire area. However, the existence of deep fluid circulation in the central part as well, cannot be excluded. The absence of deep fluid signatures at this part can be attributed to the fact that they might be masked by the mixing of huge amounts of runoff water, which strongly recharges this area.

The worldwide distribution of springs in which $\mathrm{HCO}_{3}$ concentration exceeds $1000 \mathrm{mg} / \mathrm{l}$ generally coincided with major seismic belts (King et al., 1993). In the margins of the region ${ }^{222} \mathrm{Rn}$ and $\mathrm{HCO}_{3}$ exhibit a positive correlation, where both reach the highest values $\left(8.2 \mathrm{kBqm}^{-3}\right.$ and $600 \mathrm{mg} / \mathrm{l} \mathrm{re}-$ spectively). These relatively high values could be attributed to the presence of $\mathrm{CO}_{2}$ uprising from deep, interacting with clay strata through active vertical faults of the region. The enhanced presence of $\mathrm{CO}_{2}$ as typical gas phase along an active fault acts as catalyst for water-rock interaction processes. These necessarily involve the existence of a belt of fluid geochemistry anomalies that persist until the $\mathrm{CO}_{2}$ reactions are present (Pizzino et. al, 2004a). The latter display a rough positive correlation between the variables indicating that increasing ${ }^{222} \mathrm{Rn}$ activities are prevailingly due to increasing water- rock interaction, which releases both major ion and ${ }^{222} \mathrm{Rn}$ and its parents to the groundwaters (D’Alessandro \& Vita, 2003).

\section{Conclusions}

The present study has shown evidence of possible deep circulation of fluids in the investigated area due to the fact that is crossed by very active and seismogenetic fault segments (Helike and Aigion ones), associated to upraise of deep fluids.

The radon spatial distribution was distinguished into three major zones formed along Aigion, He- 
like and Pyrgaki faults. Apart from these, two more, located in the NW and NE margins of the region were noticed. Water samples located in this region are significantly different compared to the rest. Noticeably high values of $\mathrm{EC}, \mathrm{T}_{\mathrm{w}}, \mathrm{CO}_{2}, \mathrm{Na}^{+}, \mathrm{SiO}_{2}, \mathrm{~F}^{-}, \mathrm{SO}_{4}{ }^{2-}, \mathrm{Li}$, and slightly elevated $\mathrm{U}, \mathrm{H}_{2} \mathrm{~S}$, $\mathrm{NH}_{4}{ }^{+}$and $\mathrm{B}$ concentrations together with low Eh values denote water-rock interaction processes and possible convection of fluids from great depth.

Radon stands out as a reliable tracer of recent fractured and faulted areas but also a geochemical pathfinder of deep fluid pathways in Aigion region. Thus, radon measurement may be a successful method for mapping even unknown faults or their specific features.

Since radon has been used both to locate buried faults and to monitor faults in hope of predicting earthquake activity, it is possible that the monitoring of radon emissions could be used as a tool towards this direction.

\section{References}

Al-Tamimi, M.H., Abumurad, K.M., 2001. Radon anomalies along faults in North of Jordan. Radiat. Meas 34: 397-400.

Avallone, P., Briole, A.M., Agatza-Balodimou, H., Billiris, O., Charade, C., Mitsakaki, A., Nercessian, K., Papazissi, D., Paradissis, and Veis, G., 2004. Analysis of eleven years of deformation measured by GPS in the Corinth Rift Laboratory area. C. R. Geosci.336: 301-312.

Barton, C.A., Zoback, M.D. and Moos, D., 1995. Fluid flow along potentially active faults in crystalline rocks. Geology 23 (8): 683- 686.

Briole, P., Rigo, A., Lyon-Caen, H., Ruegg, J.C., Papazissi, K., Mitsakaki, C., Balodimou, A., Veis, G., Hatzfeld, D. and Deschamps, A. 2000. Active deformation of the Corinth rift, Greece: results from repeated Global Positioning System surveys between 1990 and 1995. J. Geophys. Res. 105: 25,60525,625 .

Clarke, P.J., Davies, R.R., England, P.C., Parsons, B.E., Billiris, H., Paradissis, D., Veis, G., Cross, P.A., Denys, P.H., Ashkenazi V. and Bingley, R., 1997. Geodetic estimation of seismic hazard in the Gulf of Corinth. Geophys. Res. Lett. 24: 1303-1306.

D'Alessandro, W., \& Vita, F., 2003. Groundwater radon measurements in the Mt.Etna area. Journal of Environmental Radioactivity 65: 187-201.

Degan, P.J., Robertson, A.H.F., 1998. Mesozoic- early Tertiary passive margin evolution of the Pindos ocean (NW Peloponnese, Greece). Sedimentary Geology 117:33-70.

Durrani, S.A., Ilic, R. (Eds.), 1997. Radon Measurements by Etched Track Detectors: Application to Radiation Protection, Earth Sciences and the Environment. World Scientific, Singapore.

Fleury, J.J., 1980. Evolution d'une platforme et d'un bassin dans leur cadre alpin: les zones de GavrovoTripolitze et du Pinde-Olonos. Soc. Goel. Nord, Spec. Publ. 4.

Gundersen, L.C.S., Linda, C.S., 1991. Radon in sheared igneous and metamorphic rocks. In: Gundersen, L.C.S., Wanty, R.B. (Eds.), 1991. Field Studies of Radon in Rocks, Soil and Water, US Geol. Survey Bull.39-50.

Gudmundsson, A., Berg, S.S., Lyslo, K.B. \& Skurtveit, E., 2001. Fracture networks and fluid transport in active fault zones, J. Struct. Geol. 23, 343-353.

Ioannides, K., Papachristodoulou, C., Stamoulis, K., Karamanis, D., Pavlides, S., Chatzipetros, A. and Karakala, E., 2003. Soil gas radon: a tool for exploring active fault zones, App. Radiat. Isots. 59: 205213.

Katsanou, K., 2007. Environmental and hydrogeological study of the hydrological basins in the broader 
area of Aigion region by the use of hydrochemical methods. Master thesis. University of Patras, in Greek.

King, C.Y., 1986. Gas Geochemistry Applied to Earthquake Prediction: An Overview. J. Geophys. Res. 91, 12, 269-12,281.

King, C.Y., 1990. Gas-geochemistry approaches to earthquake prediction. In Proc. International Workshop on Radon Monitoring in Radioprotection, Environmental Radioactivity and Earth Sciences, ITCP, Triest, Italy, April 13-14, 1989 (eds. L. Tommasino, G. Furlan, H. A. Khan, and M. Monin) (World Press, Singapore 1990) 244-274.

King, C.Y., Zhang, W. and King, B.S., 1993. Radon anomalies on three kinds of faults in California. Pure Appl. Geophys. 141: 111-124.

Koukouvelas, I. K. \& Papoulis, D., 2009. Fluid involvement in the active Helike normal Fault, Gulf of Corinth, Greece. J. Struct. Geol. 31: 237-250.

Koukouvelas, I.K., Stamatopoulos, L., Katsanopoulou, D., Pavlides, S., 2001 . A palaeoseismological and geoarchaeological investigation of the Eliki fault, Gulf of Corinth, Greece. J. Struct. Geol. 23: 531543.

Koukouvelas, I.K., 1998. The Egion fault, earthquake-related and long term deformation, Gulf of Corinth, Greece. Journal of Geodynamics 26: 501-513.

Koukouvelas, I.K., Doutsos, T.T., 1996. Implications of structural segmentation during earthquakes: the 1995 Egion earthquake, Gulf of Corinth, Greece. J. Struct. Geol. 18(12): 1381-1388.

Kresl, M., Vakova, V., Klecka, M., 1993. Radon in soils overlaying several tectonic zones of the south Bohemian Moldanubicum. Jb. Geol. B. A. 136: 799-808.

Mancini, C., Quattrocchi, F., Guadoni, C., Pizzino, L., Porfidia, B., 2000. ${ }^{222}$ Rn study throughout different seismotectonical areas: comparison between different techniques for discrete monitoring, Ann. Geofis. 43 (1): 31-60.

Moussa, M.M., Gabar, A., Arabi, M.E., 2003. Soil radon survey for tracing active fault: a case study along Qena- Safaga road, Eastern Desert, Egypt. Radiat. Meas 37: 211-216.

Nikas K., 2004. Hydrogeological conditions of NW Achaia. PhD Study. University of Patras.

Nishimura, S., Katsura, I., 1990. Radon in soil gas: application in exploration and earthquake prediction In: Durrance, E.M.(Ed.). Geochemistry of Gaseous Elements and Compounds. The Ophrastus Publication, S.A. Athens, 497-533.

Pavlides S.B., Koukouvelas I.K., Kokkalas S., Stamatopoulos L., Keramydas D., Tsodoulos I., 2004. Quaternary International 115-116: 139-154.

Pe-Piper, G., Piper, D.W.J., 1984. Tectonic setting of the Mesozoic Pindos basin of the Peloponnese, Greece. Geol. Soc. Lond. Spec. Publ. 17: 563-568.

Pizzino, L., Burrato, P., Quattrocchi, F. \& Valensise G., 2004a. Geochemical signatures of large active faults: The example of the 5 February 1783, Calabrian earthquake (southern Italy). Journal of Seismology 8: 363-380.

Pizzino, L., Quattrocchi, F., Cinti, D., Galli, G., 2004b. Fluid geochemistry along the Eliki and Aigion seismogenic segments (Gulf of Corinth, Greece). Comptes Rendus Geosciences 336: 367-374.

Poulimenos, G., Albers, G. and Doutsos, T., 1989. Neotectonic evolution of the central section of the Corinth graben.Z.dt. geol. Ges 140: 173-182.

Poulimenos, G., 1993. Tectonics and sedimentation in the western Corinth graben. Neues Jahrbuch fuer Geologie und Palaontologie Monatshefte 10: 607-630.

Poulimenos, G., Zeilidis, A., Kontopoulos, N. and Doutsos, T., 1993. Geometry of the trapezoidal fan deltas and their relationship to extensional faulting along the south-western margins of the Corinth rift, 
Greece. Basin Research 5: 179-192.

Quattrocchi, F., 1999. In Search of Evidence of Deep Fluids Discharges and Pore Pressure Evolution in the Crust to Explain the Seismicity Style of the Umbria-Marche 1997 -1998 seismic sequence (Central Italy). Annali di Geophysica 42 (4): 609-636.

Richon, P., Bernard, P., Labed, V., Sabroux, J.C., Beneïto, A., Lucius, D., Abbad, S. and Robe M.C., 2007. Results of monitoring ${ }^{222} \mathrm{Rn}$ in soil gas of the Gulf of Corinth region, Greece Radiat. Meas 42(1): 8793.

Robertson, A.H.F., Clift, P.D., Degnan, P.J., Jones, G., 1991. Palaeogeographic and palaeotectonic evolution of the Eastern Mediterranean Neotethys. Palaeogeogr. Palaeocl. Palaeoecol. 87: 289-343.

Singh, M., Kumar, M., Jain, R.K. and Chatrath, R.P., 1999. Radon in ground water related to seismic events. Radiat. Meas. 30: 465-469.

Skourlis, K., Doutsos, T., 2003. The Pindos Fold-and-thrust belt (Greece): inversion kinematics of a passive continental margin. Int. J. Earth Sci. 92: 891-903.

Tselentis G.A., Melis N.S., Sokos E. and Papatsimpa K., 1996. The Egion June 15, 1995 (6.2 ML) earthquake, Western Greece. Pure Appl. Geophys., 147, 83-98.

U.S. Environmental Protection Agency 1976. Quality criteria for water. Washington, DC, 501 pp.

Zelilidis, A., 2000: Drainage evolution in a rifted basin, Corinth graben, Greece. Geomorphology, 35: 69-85. 